\title{
Capnographic detection of anaesthesia circle valve malfunctions
}

\begin{abstract}
To determine whether capnogrophic waveforms can characterize valve malfunction of the anaesthesia circle, which would enable such problems to be identified and rectified immediately, we monitored capnographic respiratory waveforms during anaesthesia with simulated circle valve malfunctions. Ten mongrel dogs were ancesthetized with pentobarbitone, 25 $\mathrm{mg} \cdot \mathrm{kg}^{-1} \mathrm{IV}$, and halothane, 0.5 to I per cent. Respiratory gas was sampled from the elbow of the circle system for capnographic monitoring, At fresh gas flow rates of 2.5 or $5 \mathrm{~L} \cdot \mathrm{min}^{-1}$ during consecusive periods of controlled and spontaneous ventilation, the inspiratory value, the expiratory valve, or both valves of the circle system were opened for $15 \mathrm{~min}$. Inspired $\mathrm{CO}_{2}$ conceniration increased significantly every time a valve was opered, except during spontaneous breathing at $5 \mathrm{~L} \cdot \mathrm{min}^{-1}$. At 2.5 $L \cdot \mathrm{min}^{-5}$, inspired $\mathrm{CO}_{2}$ increased from baseline $100.41 \pm 0.28$ per cent with the inspiratory valve opened and so $2.22 \pm 1.72$ per cent with the expiratory valve opened during controlled ventilation and to $0.43 \pm 0.20$ per cent and $2.02 \pm 1.28$ per cent, respectively, during spontaneous ventilation. Inspired $\mathrm{CO}_{2}$ increased to almost I per cent when the inspiratory valve was open and to $\geq 1.89$ per cent when the expiratory valve was open. The effects with the expiratory valve open and with both valves open were similar. Capnograms were affected in characteristic ways by the valve malfunctions.
\end{abstract}

\section{Key words}

CARBON DIOXIDE: measurement; COMPLICATIONS: accidents; EQUIPMENT: anaesthesia circle valves; MEASUREMENT TECHNIQUES: capnography; MONITORING: carbon dioxide, ventilation. VENTILATION.

From the Departments of Anesthesiology and Pediatrics, University of Florida College of Medicine, Gainesville, FL. Address correspondence to: Dr Berman, Department of Ancsthesiology, Box J-254, J. Hillis Miller Health Center, Gainesville, FL 32610-0254.
Capnographic waveforms in one reported case led to the discovery of malfunction of an expiratory valve of the circle system during anaesthesia. ${ }^{1}$ This experience suggested that certain malfunctions in the anaesthesia circle system likely have a consistent effect on respiratory values. Therefore, since capnography portrays respiratory $\mathrm{CO}_{2}$ in a reproducible fashion, perhaps circle system malfunctions would be characterized by particular types of capnographic waveforms. If this were the case, capnography would enable valve malfunctions to be identified and rectified more rapidly than would be possible by trying to detect trends in one or more sets of numcrical data. Indeed, the pattern of the contamination with expiratory gases is constant. This change would enable the anaesthesiologist to determine the possibility of a valve leak before changes in the patient's gases were dramatic or before adjustments in flow would be necessary to compensale for the admixture of the gases.

We designed a study to evaluate capnograms during various ventilatory conditions commonly used during anaesthesia.

\section{Methods}

Ten mongrel dogs weighing 15 to $20 \mathrm{~kg}$ were anaesthetized with pentobarbitone, $25 \mathrm{mg} \cdot \mathrm{kg}^{-1} \mathrm{IV}$, and their tracheas intubated with an $8.0 \mathrm{~mm}$ Hi-Low jet tracheal tube (National Catheter Co., Argyle, Wis.), which has a sampling port in the middle of the tube. An arterial line was placed percutaneously into the femoral artery for blood gas analysis (IL 713 Blood Gas Analyzer, Instrumentation Laboratories, Lexington, Mass.). The dogs were connected to a standard anaesthesia circle system and anaesthesia was maintained with 0.5 to 1.0 per cent halothane in 30 per cent $\mathrm{O}_{2}$ and 70 per cent nitrogen throughout the experiment. For part of the study, animals were paralyzed with pancuronium, $0.1 \mathrm{mg} \cdot \mathrm{kg}^{-1}$, and ventilation was controlled (Ohio Anesthesia Ventilator, Ohio Medical Products, Madison, Wis.) to keep $\mathrm{PaCO}_{2}$ at $40 \mathrm{mmHg}$.

For respiratory gas monitoring, gas was sampled from the elbow of the circle system and the mid-cuff port of the endotracheal tube and was routed to a capnograph (Godart-Statham, Bilthoven, Holland); $\mathrm{CO}_{2}$ waveform tracings were made with a $7 \mathrm{D}$ recorder (Grass Instrument 
TABLE Inspired and expired $\mathrm{CO}_{2}$ and $\mathrm{PaCO}_{2}$ during controlled and spontaneous ventilation with malfunetioning valves in 10 dog5

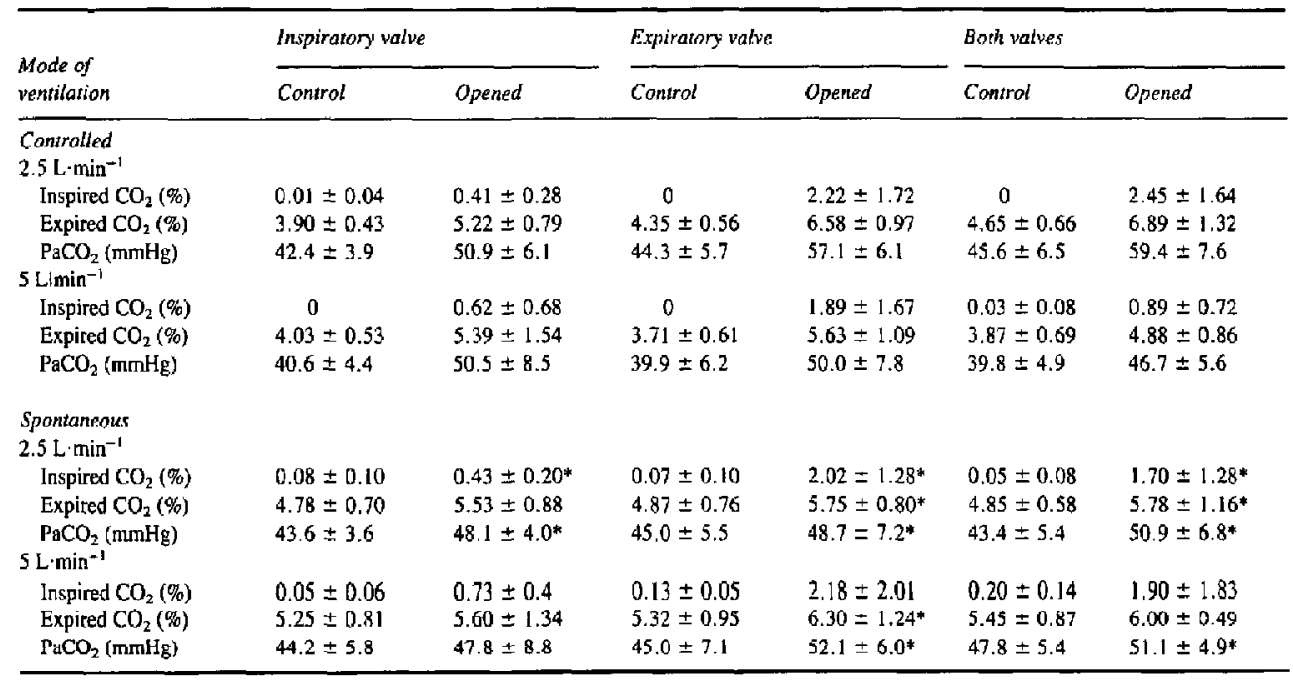

Co., Quincy, Mass.). The anacsthetic circle system studied consisted of a fresh gas inlet upstream from the inspiratory valve and downstream from the absorber. Hence gas would collect in the absorber and the components between the expiratory unilateral valve and the absorber. This system is the one most commonly used, although other systems are possible and mixing of expired gases are possible at different locations.

With cach dog, spontaneous and controlled ventilation at fresh gas flow rates of 2.5 and $5 \mathrm{~L} \cdot \mathrm{min}^{-1}$ were applied in random order with the anaesthesia circle system intact for $15 \mathrm{~min}$ and with valve malfunctions simulated by propping open either the inspiratory or expiratory valve or both valves. After 15 minutes of each condition, capnograph waveforms were recorded and blood was sampled for gas analysis. Values were allowed to retum to baseline with both valves functioning after each test. Data were analyzed by analysis of variance with Duncan's test or with least significant difference, pairwise $t$ test; analysis was performed by the Statistical Analysis System (SAS Institute, Cary, NC) on an IBM PC computer.

\section{Results}

The effect of the valve malfunctions followed a consistent pattern (Table) that was reflected in the capnogram waveforms (Figure). With the inspiratory valve open, the waveform plateau was prolonged. Waveforms with the expiratory valve and with both valves opened were similar - waveforms never returned to baseline and the plateau was elevated $(\mathrm{p}<0.05$ ). All three types of malfunction elevated expired $\mathrm{CO}_{2}$ to similar levels $(\boldsymbol{p}>0.05)$. Inspired $\mathrm{CO}_{2}$ levels differed by type of malfunction; values with the expiratory valve and both valves opened were similar and were higher than expired $\mathrm{CO}_{2}$ levels $(p<0.05$ ).

Comparison at different flow rates did not show any significant differences nor did a comparison of spontaneous and controlled ventilation. Expired $\mathrm{CO}_{2}$ levels were all higher than control values but did not differ from each other.

\section{Discussion}

The function of valves in the anaesthesia circle system is to eliminate rebreathing. If these valves remain closed, the effect of the malfunction is obvious and readily detected because gas flow is completely obstructed. The effect of inappropriate opening of valves is not as obvious and, once the effect manifests, discovering the problem may take additional time.

Using a capnograph to detect anaesthesia ventilation malfunctions has been inferred in several sources, ${ }^{2.3}$ but the magnitude of the malfunction has not been quantitated. Our study shows that capnograms portray a consistent problem and may enable the problem to be corrected almost as soon as it occurs. Increases in end-expiratory $\mathrm{CO}_{2}$ could be caused by hypoventilation, hence, according to our data, the inspiratory $\mathrm{CO}_{2}$ waveform would give more information about valve leaks.

In this study, capnograms reflected value malfunc- 

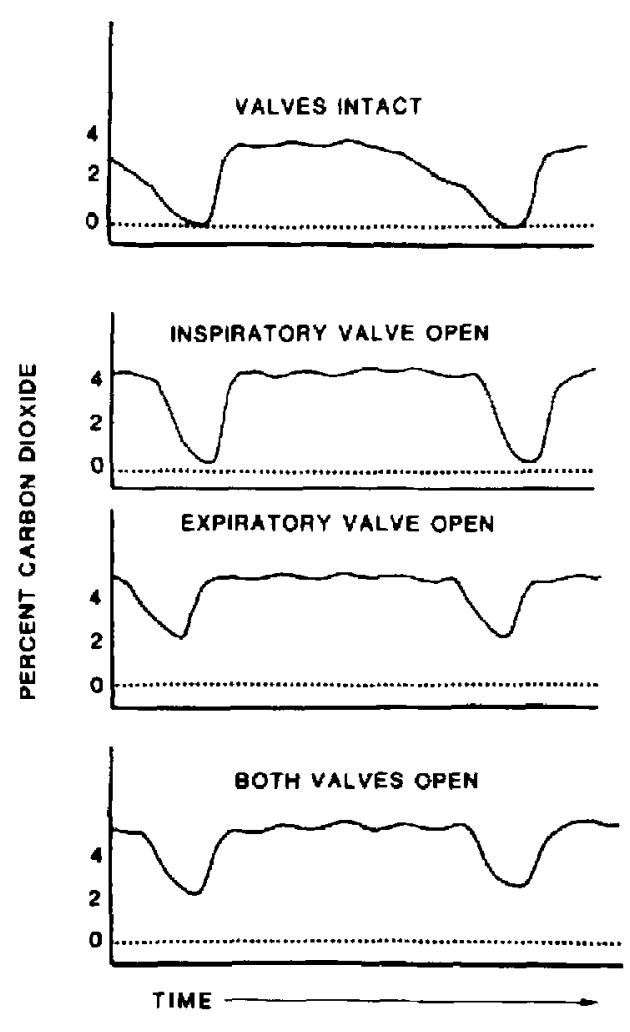

FGURE Capnograms obtained with an anaesthesia circle system with the inspiratory or expiratory valve or both yalves upened compared with eapnogram when valves are funetioning nomally. Note the prolonged plateaus with all malfunctions

tions, which indicates that capnographic waveforms enables rapid correction of malfunctions before adverse effects occur.

\section{References}

1 Pytes $S T$, Berman $L S$, Modell $J H$. Expiratory valve dysfunction in a semiclosed circle anesthesia circuit - verification by analysis of carbon dioxide wavefom. Anesth Analg 1984; 63: 536-7.

2 Gravenstein JS, Paulus DA. Clinical Monitoring Practices. 2nd ed. Philadelphia: JB Lippincott, 1987, p 192.

3 May WS, Heavner JE, McWhorter D, Racz G. Capnography in the Operating Room. New York: Raven Press, $1985, \mathrm{p} 6$.

\section{Résumé}

Afin de déterminer si l'onde obtemue par capnographie peut détecier un malfonctionnement des valves du circuil anesthésique permettant une correction immédiate, on a étudié ces. tracés durant l'anesthêsie en simulant un malfonctionnement de ces valves. Dix chiens bâtards ont été anesthésiés avec du pentobarbital, $25 \mathrm{mg} \cdot \mathrm{kg}^{-1} \mathrm{I}$ er de l'halothane 0.5 a I pour cent. Les gaz ont été échantillonnes du coude du circuit pour étude capnographique. Des flots de gaz frais de 2.5 à $5.0 \mathrm{~L} \cdot \mathrm{min}^{-1}$ durant des périodes consécutives de ventilation contrôlée et spontanée, la vaive inspiratoire, da valve expiratoire ou les desx valves du tircuit ont été ouverts pour 15 minutes. Les concentrations de $\mathrm{CO}_{2}$ inspirées augmentèrent significativement dे chaque fois que la valve était ouverte, excepté lors de la respiration spontanée d $5 \mathrm{~L} \cdot \mathrm{min}^{-1}$. A $2.5 \mathrm{~L} \cdot \mathrm{min}^{-1}$ le $\mathrm{CO}_{2}$ inspire augmenta de la ligne de base d $0.41 \pm 0.28$ pour cent quand la valve inspiratoire était ouverte et d $2.22 \pm 1.72$ pour cent quand la valve expiratoire était ouverte lors de la ventilation contrôlé et à $0.43 \pm 0.20$ pour cent et $2.02 \pm 1.28$ pour cent respectivement, durant la ventilation spontanée. Le $\mathrm{CO}_{2}$ inspiré augmenta jusqu' à environ 1 pour cent quand la valve inspiratoire était ouverte et à \pm 1.89 pour cent quond la valve expiratoire était ouverte. Des résultats similaires furent obtenus avec la valve expiratoire ouverte et avec les deux valves ouvertes. La capnographie était caracteristique lors des malfoncionnements de valve. 